\title{
Abstracts of Articles
}

"The Erosion of Ideological Hegemony and Royal Power and the Rise of Post-war Malay Nationalism, 1945-46" by Cheah Boon Kheng

Inspite of the impact of British rule and the economic competition presented by a large non-Malay migrant population, Malay nationalism was late in maturing before 1941. The writer's explanation is that while most other factors were contributing to a peninsular-wide national unity of the Malays, respective State loyalty and allegiance to the rulers circumscribed the development of the full bloom of Malay nationalism. He argues that ideological hegemony and royal power are crucial to an understanding of the Malay mind before 1941 and were based on a centuries-old tradition consisting of the contrasted notions of derhaka and daulat tuanku. He integrates the findings from a variety of sources in Malaysian history and social sciences to show how this tradition finally broke down with popular Malay protests against the Malayan Union plan of the British in 1945-46.

"The Post-1945 Food Shortage in British Malaya" by Paul H. Kratoska

This article discusses the food situation in Malaya during the Japanese Occupation, efforts made by post-war British administrations to increase food supplies, and the substantial contributions of smuggling and the black market toward meeting Malaya's nutritional requirements from 1945 through 1948.

"Tan Cheng Lock and the Chinese Education Issue in Malaya" by Tan Liok Ee

This paper examines Tan Cheng Lock's involvement in the Chinese education issue between November 1952 and March 1958. As president of the Malayan Chinese Association, Tan was a central figure in arranging a historic meeting between Chinese educationists and UMNO leaders. The compromise arrived at during this meeting had far-reaching consequences on the future of Chinese education in Malaya.

"Commerce and Conflict: Two Views of Portuguese Melaka in the 1620s" by Sanjay Subrahmanyam

The early 17 th century was a period of great stress and strain for the commercial centre of Melaka on the Malay Peninsula. After a century or so of Portuguese rule, the town found itself in the 1620 s under twin threats. On the one hand, the commerce of Melaka was threatened by the loss of trade to some parts of Indonesia, and Dutch attacks on other shipping lines. On the other hand, the town itself was threatened by imminent siege, not merely by the Dutch Company but by the Sultanate of Aceh under Iskandar Muda. These threats translated into a crisis in finances, and various schemes were floated to ensure the physical and financial viability of Melaka in the period. The paper seeks to examine these schemes within a changing commercial context, when the commercial role of Melaka was redefined perforce.

"The Origin of Modern Official State Ideology in Thailand" by Eiji Murashima

The Thai official state ideology, centered on the triumvirate of Nation. Religion and King, has been associated with the Western-educated King Vajiravudh. This study shows how the official state ideology orignated in the 1880 s during the reign of his father, King Chulalongkorn, and shows the continuity of his fundamental political ideas with those of the previous Thai generation. 
"China and Southeast Asia: The Revolutionary Perspective, 1951" by R.B. Smith

An analysis of changing Communist strategy in Southeast Asia in the years 1950 51, with special reference to the role of the Chinese Communist Party and its relations with the Viet Minh and the Malayan Communist Party. It uses both monitored broadcasts (from Communist radio stations) and the British archives; and it raises questions about a possible change in the British perception of Soviet and Chinese roles in the region between 1948 and 1951.

"Malaysian-American Relations during Indonesia's Confrontation against Malaysia, 1963-66" by Pamela Sodhy

Indonesia's Confrontation policy against Malaysia from 1963 to 1966 marked a turning point in Malaysian-American relations because it led to America's first direct involvement in Malaysia's political affairs - through the Robert Kennedy mission in 1963, the invitation to the Malaysian Premier for a visit in 1964, the offer of military aid, and through siding with Malaysia in the United Nations.

"Urbanization Trends in Southeast Asia: Some Issues for Policy" by Gavin W. Jones

The apparent Southeast Asian paradox of fairly slow urbanization but rapidly growing urban populations is due to continued high rates of natural increase, especially in rural areas. Southeast Asian countries differ greatly in the nature of their urban hierarchies, and the appropriate policy goals and strategies therefore also differ. In countering growing urban primacy, indirect approaches emphasizing macro-economic and sectoral policies conducive to more dispersed patterns of urban growth have greater potential impact than direct attempts to slow the growth of large city populations. Greater decentralization of power and decision making over resource allocation is also needed. 